\title{
PENGAWASAN SEBAGAI INSTRUMEN PENEGAKAN HUKUM PADA PENGELOLAAN USAHA PERTAMBANGAN MINERAL DAN BATUBARA*
}

\author{
Fenty U. Puluhulawa \\ Universitas Negeri Gorontalo \\ E-mail: fentyp@yahoo.com
}

\begin{abstract}
This research is intended to explain the monitoring as an instrument of law enforcement, to examine how the intensity of supervision on the business of mineral and coal, which is expected to support the establishment of law enforcement. The method in this study are socio juridical, with qualitative and quantitative methods. Research shows that in terms of planning and coordination of implementation supervision has not been implemented optimally, so that does not yet support the establishment of law enforcement. Based on this, it is necessary to the formation of an integrated environmental licensing system specialized in the management of the mining business.
\end{abstract}

Keywords: monitoring, law enforcement, mining

\begin{abstract}
Abstrak
Penelitian ini dimaksudkan untuk menjelaskan pengawasan sebagai salah satu instrumen penegakan hukum, dengan mengkaji bagaimana intensitas pelaksanaan pengawasan pada usaha pertambangan mineral dan batubara, sehingga diharapkan dapat mendukung terwujudnya penegakan hukum. Metode pendekatan dalam penelitian ini adalah sosio yuridis, dengan metode analisis secara kualitatif dan kuantitatif. Hasil Penelitian menunjukkan bahwa baik dari aspek perencanaan maupun koordinasi pelaksanaan pengawasan belum dilaksanakan secara optimal, sehingga belum mendukung terwujudnya penegakan hukum. Berdasarkan hal tersebut, maka diperlukan pembentukan sistem perizinan lingkungan yang terpadu khusus dalam pengelolaan usaha pertambangan.
\end{abstract}

Kata Kunci: pengawasan, penegakan hukum, pertambangan

\section{Pendahuluan}

Bumi dan segala isinya yang diciptakan oleh Allah SWT merupakan suatu karunia yang sangat sempurna. Hal ini telah diatur dalam Firman Allah SWT Surat Al Mulk (Surat ke-67) ayat (3) yang artinya Kamu sekali-sekali tidak melihat pada ciptaan Tuhan Yang Maha Esa sesuatu yang tidak seimbang. Maka lihatlah berulang-ulang, adakah kamu lihat sesuatu yang tidak seimbang? Dilanjutkan dengan ayat (4) yang artinya, kemudian pandanglah sekali lagi, niscaya penglihatanmu akan kembali kepadamu dengan tidak menemukan sesuatu cacat dan penglihatanmu itupun dalam keadaan payah. Selanjutnya dalam Surat Al A'Raaf (Surat ke-7) ayat (56) diatur bahwa dan janganlah kamu

Artikel ini merupakan bagian dari Disertasi yang dana penelitiannya sebagian dibiayai oleh DIKTI. membuat kerusakan di muka bumi, sesudah (Allah) memperbaikinya dan berdoalah kepadaNya dengan rasa takut (tidak akan diterima) dan harapan (akan dikabulkan). Sesungguhnya rahmat Allah amat dekat kepada orang-orang yang berbuat baik. Ketentuan yang tercantum dalam firman Allah di atas, pada hakikatnya menganjurkan setiap manusia untuk selalu menjaga keseimbangan terhadap lingkungan serta tidak melakukan tindakan semena-mena yang mengakibatkan timbulnya efek adanya kerusakan lingkungan, yang pada akhirnya menghancurkan kehidupan untuk jangka panjang.

Perhatian dunia internasional terhadap masalah pemanfaatan, pengelolaan serta pelestarian sumber daya alam telah diwujudkan dengan disepakatinya berbagai deklarasi, seperti Deklarasi Stockholm, Deklarasi Nairobi, Deklarasi Rio De Jeneiro, Deklarasi Johannesburg 
maupun The Earth Charter. Konferensi internasional ini telah melahirkan konsep sustainable development yakni pembangunan jangka panjang dan berkelanjutan.

Terlaksananya pembangunan jangka panjang dan berkelanjutan tersebut memerlukan pengetahuan yang serius baik dari segi yuridis, maupun teknis dalam pemanfaatan sumber daya alam yang tersedia. ${ }^{1}$ Komitmen tentang pengelolaan lingkungan hidup di Indonesia telah diatur dalam Pasal $28 \mathrm{H}$, ayat (1) dan Pasal 33 Ayat (3), dan (4) UUD 1945. Selanjutnya dalam UU Nomor 17 Tahun 2007 tentang Rencana Pembangunan J angka Panjang Nasional, UU Nomor 39 Tahun 1999 tentang Hak Asasi Manusia, maupun UU Nomor 32 Tahun 2009 tentang Perlindungan dan Pengelolaan Lingkungan Hidup (selanjutnya di-singkat UUPPLH). Hal ini semakin mempertegas bahwa negara bertanggung jawab untuk memenuhi hak warga negara, yakni untuk mendapatkan lingkungan baik dan sehat sesuai dengan ketentuan yang berlaku. Negara menjamin bahwa pemanfaatan sumber daya alam akan mem-berikan manfaat yang sebesar-besarnya bagi kesejahteraan dan mutu hidup rakyat, baik bagi generasi masa kini, mau pun yang akan datang. Menurut Gunawan, lingkungan hidup adalah bagian yang tidak terpisahkan dari urusan Hak Asasi Manusia. ${ }^{2}$ Oleh sebab itu kegiatan pemanfaatan sumber daya alam yang bertentangan dengan undang-undang, seyogyanya dapat dicegah.

Persoalan lingkungan hidup pada pertambangan dalam kenyataannya di Indonesia, banyak dipersoalkan. Penyebabnya adalah timbulnya dampak negatif dalam pengusahaan bahan galian sebagai akibat dari usaha pertambangan berupa, rusaknya hutan, tercemarnya laut, terjangkitnya penyakit, serta terjadinya konflik masyarakat pada lingkar tambang. Dampak langsung adalah kerusakan ekologis serta peluang terjadinya banjir dan tanah longsor. Lim-

\footnotetext{
1 Puspa Melati Hasibuan, "Dampak Penambangan Bahan Galian Golongan C Terhadap Lingkungan Sekitarnya Di Kabupaten Deli Serdang", J urnal Equality, Vol. 11, No. 1, Februari 2006, Hal. 26-28.

2 Gunawan, Hak Atas Lingkungan dan Tanggung Jawab Lingkungan Korporasi, Jurnal Hukum Jentera, Nomor 18, Tahun IV, 2008, hlm. 46.
}

bah tailing pada penambang emas mengandung bahan beracun yang menyebabkan ketidakmampuan masyarakat dalam memperoleh lingkungan yang sehat. ${ }^{3}$

Persetujuan pertambangan pada hutan lindung membawa dampak negatif bagi sektor kehutanan di Indonesia. Konflik pertambangan lebih dianggap sebagai persoalan administratif, oleh karena lemahnya pengawasan inspektur tambang, sehingga dihindari penyelesaian meIalui pengadilan. ${ }^{4}$

Kaltim Post mencatat bahwa, di Provinsi Kalimantan Timur, luas KP batubara secara keseluruhan adalah 3,08 juta hektare. Data Dinas Pertambangan dan Energi Kalimantan Timur bahwa total KP adalah 1.180 KP. Berdasarkan jumlah tersebut seluas 391 ribu hektare berasal dari 260 izin KP yang sudah masuk pada tahap eksploitasi. Ditinjau dari jumlah izin KP, maka Kutai Kartanegara menempati peringkat teratas dengan 271 izin KP yang diikuti dengan Kutai Barat 138 izin KP dan Paser 73 izin KP selanjutnya kabupaten/kota lainnya. Sejumlah Lembaga Swadaya Masyarakat (selanjutnya disingkat LSM) bidang lingkungan baik di Kalimantan Selatan, maupun Kalimantan Timur membenarkan keengganan perusahaan mereklamasi tambang karena pengawasan yang minim. ${ }^{5}$ Fakta empiris sebagaimana diuraikan di atas menunjukkan bahwa ada kecenderungan lemahnya, intensitas pelaksanaan pengawasan dan hal ini berdampak pada belum terwujudnya pelaksanaan penegakan hukum. Oleh sebab itu relevan apabila dalam rangka mengefektifkan penegakan hukum administrasi, maka seyogyanya dimulai dari upaya yang sifatnya preventif yakni meIalui pelaksanaan pengawasan. Melalui upaya preventif, diharapkan penyelesaian secara represif melalui pengadilan dapat diminimalkan.

\footnotetext{
3 Lihat dan bandingkan dengan Yusni Yetti, "Analisis Kebijakan AMDAL Dalam Mencegah Kerusakan", Lembaran Publikasi Lemigas, Vol. 41, No. 3, Desember 2007, Hal. 24

4 Supriatna Suhala, 2009, "Penyelesaian Konflik Pertambangan Butuh Lembaga Khusus", tersedia di website www. majalahtambang.com, diakses tanggal 2 April 2009.

5 Kompas, Edisi 25 J anuari 2010.
} 


\section{Permasalahan}

Berdasarkan latar belakang di atas, maka permasalahan yang akan dibahas pada artikel ini adalah mengenai intensitas pengawasan, yang mendukung pelaksanaan penegakan hukum pada pengelolaan usaha pertambangan mineral dan batubara.

\section{Metode Penelitian}

Penelitian ini adalah penelitian hukum dengan fokus kajian pada aspek sosio yuridis (sosio legal research). ${ }^{6}$ Ada dua indikator yang akan dianalisis yakni, perencanaan dan koordinasi pengawasan. Pada tataran tersebut akan dianalisis realitas melalui gejala empirik yang dapat diamati pelaksanaannya melalui penegakan hukum dalam masyarakat.

Penelitian dilaksanakan di Provinsi Kalimantan Timur dengan lokasi Kabupaten Kutai Kartanegara mewakili lokasi untuk wilayah pertambangan batubara, serta Provinsi Sulawesi Selatan mewakili lokasi untuk pertambangan mineral logam. Sampel wilayah ditetapkan secara purposive. Populasi dalam penelitian ini adalah pihak-pihak yang terkait dengan objek penelitian, yang terdiri dari seluruh komponen terlibat dalam melaksanakan tugas pengawasan. Kelompok tersebut di atas merupakan kelompok yang memiliki derajat keseragaman (degree of homogeneity), sehingga penetapan sampel yang sifatnya purposive dalam jumlah yang tertentu dari seluruh populasi dianggap cukup representatif. Sampel dalam penelitian ini terdiri dari warga masyarakat, pengawas pertambangan aparat pada instansi pemerintah yang terkait secara langsung, dipilih secara purposive. Secara keseluruhan sampel berjumlah 80 orang.

Data yang berupa angka diperoleh melalui penelitian akan dianalisis secara kuantitatif dengan menggunakan prosentase, selanjutnya diolah dan dianalisis melalui panduan landasan teori, dengan menggunakan teknik analisis kualitatif. Data sekunder pada penelitian ini akan

\footnotetext{
6 Soetandyo Wignyosoebroto, "Sedikit Penjelasan Tentang Kajian-Kajian Hukum Dari Perspektif IImu Sosial", Jurnal Warta Hukum dan Masyarakat, No 1 Tahun ke 1 November 1995, hlm. 3
}

dianalisis melalui cara melakukan penafsiran dengan membandingkannya pada bahan-bahan hukum, serta konsep hukun yang relevan dengan penelitian dimaksud.

\section{Pembahasan \\ Perencanaan}

Sebagai konsekuensi dari diterbitkannya Izin Usaha Pertambangan (IUP), maka langkah selanjutnya adalah melakukan pengawasan. Pengawasan merupakan salah satu unsur dalam kegiatan manajemen. Pengawasan pada prinsipnya dilakukan sebagai upaya preventif apakah kegiatan dilakukan sesuai ketentuan yang ada. ${ }^{7}$ Pengawasan pada pengelolaan usaha pertambangan pada prinsipnya bertujuan agar pemegang IUP lebih terarah dalam melakukan aktivitas dalam rangkaiannya dengan usaha pertambangan, sehingga tidak menyimpang dari perintah dan larangan yang telah ditetapkan dalam izin. Secara teori George R. Terry berpendapat bahwa pengawasan dimaksudkan untuk menentukan apa yang telah dicapai, mengevaluasi dan menerapkan tindakan korektif jika perlu, untuk dapat memastikan hasil yang sesuai dengan rencana. ${ }^{8}$ Relevan dengan pendapat tersebut, maka pengawasan mutlak diperlukan dalam rangkaian dengan pegelolaan usaha pertambangan sesuai dengan prinsip tujuan pengawasan yakni agar tidak menyimpang dari perintah dan larangan yang telah ditetapkan dalam izin. Oleh sebab itu sebagai bagian dari fungsi manajemen, perencanaan menjadi semakin penting untuk efektivitasnya tugas pengawasan, dan sebagai realisasi dari tugas penegakan hukum sebagaimana yang telah diamanatkan oleh peraturan perundang-undangan. Sukses tidaknya rangkaian tugas pengawasan ditentukan oleh perencanaan awal dari kegiatan pengawasan itu sendiri.

\footnotetext{
Fenty Puluhulawa, "Substansi Hukum Tentang Pengawasan Izin Pada Usaha Pertambangan", Jurnal Pelangi IImu, Vol 3 Nomor 4, 4 September 2010, hlm. 148.

8 George R.Terry (dalam Jazim Hamidi dan Mustafa Lutfi), "Eksistensi Komisi Ombudsman Nasional dalam Mewujudkan Good Governance", Majalah Hukum Varia Peradilan, Edisi April 2009, hlm. 47.
} 
Walaupun tidak diatur secara limitatif kegiatan perencanaan pada pengawasan dalam PP 55 Tahun 2010 tentang P4UPMB dan Kepmen Pertambangan dan Energi Nomor 2555.K Tahun 1993 tentang Pelaksana Inspeksi Tambang (PIT) pada Usaha Pertambangan Umum, namun dalam kenyataannya tahapan tersebut seharusnya dilaksanakan dalam rangka efektivitasnya tugas pengawasan. Tidak diaturnya secara limitatif mengenai hal tersebut, tentunya akan berdampak pada pelaksanaan aturan pada tataran empirik. Oleh sebab itu secara normatif masih dibutuhkan penyempurnaan.

Perencanaan mutlak diperlukan mengawali pelaksanaan pengawasan untuk mewujudkan kehendak hukum yang berisi perintah dan larangan dalam bidang pertambangan. Di Kabupaten Kutai Kartanegara Provinsi Kalimantan Timur, salah satu misi yang merupakan jabaran dari visi Dinas Pertambangan dan Energi Kabupaten Kutai Kartanegara adalah, penyusunan perencanaan serta program melakukan evaluasi dalam bidang pertambangan. Sebagai realisasi dari misi tersebut, dan dalam rangkaian dengan tugas pengawasan pertambangan, maka dilaksanakan strategi melalui perencanaan. Hasil wawancara dengan Aji Wahyu Setiawan, Pelaksana Inspeksi Tambang (PIT) Fungsional Dinas Pertambangan dan Energi Kabupaten Kutai Kartanegara (tanggal 25 Oktober 2010) bahwa pengawasan pada usaha pertambangan dilaksanakan dengan berpedoman pada Kepmen Pertambangan dan Energi Nomor 2555. K Tahun 1993. Terkait dengan pengelolaan lingkungan, didasarkan pada Kepmen Pertambangan dan Energi Nomor 1211. K Tahun 1995 tentang Pencegahan dan Penanggulangan Perusakan dan Pencemaran Lingkungan Pada Usaha Pertambangan Umum. Dalam kenyataannya walaupun UUPP yang menjadi dasar pembentukan Kepmen tersebut telah diganti dengan UUPMB, namun demikian selama belum diterbitkannya Kepmen yang baru, aturan tersebut masih tetap digunakan dan dalam realisasinya masih relevan dengan kondisi saat ini. Berpedoman pada Kepmen Pertambangan dan Energi Nomor 1211.K Tahun 1995, maka setiap pengusaha tambang diwajibkan untuk menyampaikan rencana tahunan pengelolaan lingkungan. Perencanaan dibuat untuk mencegah serta mengantisipasi terjadinya pencemaran dan/atau perusakan lingkungan. Perencanaan ini untuk selanjutnya di sampaikan kepada Pelaksana Inspeksi Tambang (PIT) yang memuat rencana peruntukan lahan; teknik metode pengelolaan lingkungan; jadwal pelaksanaan pekerjaan dan penyelesaian tiap tahap reklamasi; jenis tanaman yang akan ditanami; dan perkiraan biaya.

Selain perencanaan yang dibuat oleh pihak pengusaha pertambangan, maka tugas pengawasan kegiatan pertambangan yang selama ini dilakukan oleh PIT dilaksanakan melalui tahapan perencanaan. Sebelum pengawasan dilaksanakan, sesuai dengan perencanaan beberapa hal yang telah dilakukan adalah sebagai berikut. Pertama, pemberian pedoman serta standar pelaksanaan pengelolaan usaha pertambangan; kedua, pemberian bimbingan, supervisi dan konsultasi; dan ketiga, pendidikan dan pelatihan. Selanjutnya pengawasan dilaksanakan melalui evaluasi terhadap rencana kerja serta pelaksanaan kegiatan usaha pertambangan dan inspeksi langsung ke lokasi usaha pertambangan. Evaluasi terhadap rencana kerja serta pelaksanaan kegiatan usaha pertambangan dilaksanakan melalui laporan yang dibuat setiap 3 bulan, selain itu, inspeksi langsung ke lokasi secara rutin. Sebagai pengecualian, jika terjadi kasus. Mekanisme yang sama ini berlaku pula pada Kabupaten Luwu Timur.

Berbeda dengan BLHD Kabupaten Kutai Kartanegara. Menurut Aisha Kepala Sub Bidang Advokasi Hukum Lingkungan (wawancara tanggal 25 Oktober 2010), bahwa BLHD Kabupaten Kutai Kartanegara memiliki perencanaan sendiri mengenai pengawasan terkait dengan permasalahan lingkungan pada pertambangan. Pada pelaksanaannya, walaupun melalui proses perencanaan, akan tetapi dalam implementasinya di lapangan banyak mengalami hambatan. Selain itu minimnya anggaran untuk inspeksi ke lokasi, serta jauhnya lokasi yang akan diawasi. Pengawasan melalui laporan pelaksanaan kegiatan di lapangan secara rutin dilaksanakan setiap 3 
bulan sekali. Pada Kabupaten Luwu Timur, sebelumnya Dinas Lingkungan Hidup digabung dengan Dinas Pertambangan, sehingga perencanaannya dilaksanakan bersama. Sejak tahun 2008 terjadi pemisahan antara kedua instansi tersebut, dan hal ini berdampak pada penyusunan program masing-masing pada dinas instansi masing-masing termasuk pengawasan.

Fakta di atas menunjukkan bahwa pada instansi sektoral strategi perencanaan terkait dengan pengawasan mengenai pengelolaan lingkungan sebagai realisasi dari diterbitkannya Izin Usaha Pertambangan (IUP) telah dilakukan, walaupun dalam kenyataannya belum dilaksanakan secara terpadu antara instansi sektoral. Kenyataan di atas juga membuktikan bahwa perencanaan pengawasan dilaksanakan secara sendiri-sendiri oleh masing-masing instansi sektoral yakni antara Dinas ESDM dan BLHD. Idealnya perencanaan yang dilakukan secara terpadu pada esensinya memegang peranan yang penting dan menentukan optimal tidaknya pelaksanaan pengawasan. Oleh sebab itu melalui perencanaan yang terpadu, diperlukan komitmen bersama, kesamaan persepsi, sehingga dengan demikian diharapkan seluruh rangkaian pelaksanaan pengawasan dapat terlaksana sesuai target yang ditetapkan secara terpadu melalui perencanaan, sehingga dengan demikian upaya penegakan hukum administrasi dapat dilaksanakan. Melalui pengawasan yang terpadu, maka diharapkan pelaksanaannya tidak akan menyimpang dari hakikat serta esensi dari tujuan pengawasan. Demikian pula dengan perubahan perundang-undangan yang tidak serta merta diikuti dengan perubahan sistem, karena terkait dengan belum adanya peraturan pelaksanaan. Contohnya, saat ini berlakunya UU Pertambangan Mineral dan Batubara (UUPMB) yang belum dapat berlaku secara efektif di lapangan. Secara teori menurut Ridwan salah satu motif dilakukannya pengawasan adalah koordinasi. ${ }^{9} \mathrm{Ke}-$ nyataan berdasarkan hasil wawancara di atas tidak relevan dengan pendapat yang dikemuka-

Lihat P. de Haan dan Versteden (dalam Ridwan), 2006, Hukum Administrasi di Daerah, Bandung: PT Raja Grafindo Persada, hlm. 126. kan oleh Ridwan. Koordinasi seharusnya sudah dimulai pada tahap perencanaan, sehingga dalam pelaksanaannya diharapkan dapat mendukung terwujudnya pelaksanaan penegakan hukum administrasi. Melalui pengawasan diharapkan terjalinnya keseimbangan antara pengelolaan pertambangan dan pelestarian fungsi lingkungan, sehingga diharapkan dapat mewujudkan pengelolaan pertambangan yang berwawasan lingkungan. Pelaksanaan pertambangan yang berwawasan lingkungan akan mendukung pelaksanaan konsep pembangunan untuk masa kini dan masa yang akan datang sebagaimana harapan yang telah ditetapkan melalui konferensi internasional yang telah menghasilkan berbagai deklarasi internasional.

\section{Koordinasi}

Usaha pertambangan dalam wujud pelaksanaannya secara teknis tidak dapat dilepaskan dari lembaga/instansi pemerintah lainnya secara lintas sektoral. Hal ini mengandung makna bahwa secara keseluruhan pelaksanaan usaha pertambangan seharusnya selalu melibatkan lembaga/ instansi pemerintah secara lintas sektoral untuk keberlangsungan kegiatan tersebut, khususnya terkait dengan kinerja yang berkaitan dengan pengawasan pengelolaan lingkungan hidup. Harapan keterlibatan instansi ini dimaksudkan sebagai realisasi dari diterbitkannya IUP, baik IUP Eksplorasi maupun IUP Operasi produksi yang merupakan instrumen dari penegakan hukum pada kawasan pertambangan. Oleh sebab itu idealnya pengelolaan pertambangan yang berwawasan lingkungan diharapkan akan terwujud jika terjalin hubungan kerja yang sinergis antar instansi dalam bentuk koordinasi.

Koordinasi pada hakikatnya adalah merupakan tindakan kerja sama saling menunjang untuk mendapatkan keselarasan yang pada akhirnya akan menghasilkan kerja sama yang baik antara semua pihak. Koordinasi menjadi sangat diperlukan dalam kaitannya dengan usaha pertambangan, oleh karena dalam pelaksanaannya terkait dengan persyaratan berbagai bentuk perizinan yang tidak saja merupakan kewena- 
ngan instansi teknis dalam hal ini Dinas ESDM, akan tetapi terkait dengan instansi sektoral lainnya. Keterkaitan ini tampak dalam beberapa hal tentang perizinan. Misalnya, terkait dengan Amdal dan Izin lingkungan yang melibatkan instansi Bapedalda, izin mengenai limbah B3 yang terdiri dari izin pengangkutan, penghasil, pengumpulan, pengolahan, dan izin penyimpanan yang sebagian merupakan kewenangan pemerintah pusat dan sebagian menjadi kewenangan daerah, dan jika wilayah pertambangan berada pada wilayah kabupaten/ kota, maka IUP diterbitkan oleh Dinas ESDM. Di sinilah dibutuhkan adanya koordinasi sebelum menerbitkan berbagai izin tersebut, maupun dalam melakukan pengawasan sebagai konsekuensi diterbitkannya IUP. Oleh sebab itu diperlukan norma hukum yang secara tegas mengatur. Pada tahap operasional diperlukan pemahaman yang sama dari berbagai pihak terutama pelaksana hukum di lapangan terkait dengan hal di maksud. Koordinasi mutlak diperlukan untuk terjalinnya sinergis dan khususnya dalam menyikapi permasalahan terkait dengan lingkungan sebagaimana yang tercantum dalam Pasal 28 PP Nomor 55 Tahun 2010 tentang P4UPMB, dan Pasal 13 Perda Kabupaten Kutai Kartanegara Nomor 2 Tahun 2001 yang mengatur tentang permintaan saran, pendapat dari instansi teknis terkait sebelum ditetapkannya IUP.

Para pelaksana hukum di lapangan idealnya harus memiliki pemahaman yang sama terhadap sistem serta mekanisme pengawasan. Melalui upaya penyamaan persepsi tersebut maka diharapkan dapat melakukan beberapa hal. Pertama, mewujudkan kesamaan persepsi antara aparat pengawas dalam melakukan tugas pengawasan; kedua, menyatukan tugas pengawasan dalam menyelesaikan permasalahan terkait dengan pertambangan; ketiga, memberikan suasana kondusif dalam menyelesaikan berbagai permasalahaan yang terjadi.

Koordinasi sejak tahap perencanaan awal dibutuhkan untuk menghasilkan masukan serta persepsi berguna bagi masyarakat yang berkepentingan (public interest) dalam rangka untuk meningkatkan kualitas dalam rangkaiannya de- ngan pengambilan keputusan lingkungan. Oleh sebab itu maka idealnya, sistem koordinasi pun sudah harus dirumuskan sejak awal.

Hasil penelitian baik pada Kabupaten Kutai Kartanegara maupun pada Kabupaten Luwu Timur dominan menyatakan bahwa koordinasi tentang pengawasan belum terlaksana sesuai harapan. Hal ini dapat dilihat dari 28 (70\%) jawaban responden pada Kabupaten Kutai Kartanegara. J umlah dimaksud dapat dirinci 2 (5\%) responden aparat dan 26 (65\%) responden masyarakat. Selanjutnya pada Kabupaten Luwu Timur terdapat $50 \%$ yang menjawab bahwa koordinasi belum terlaksana. Jumlah tersebut seluruhnya adalah responden masyarakat. Selanjutnya $8(20 \%)$ responden aparat pada Kabupaten Kutai Kartanegara menyatakan bahwa koordinasinya terlaksana, dan $4(10 \%)$ responden yang terdiri dari $2(5 \%)$ masyarakat dan $2(5 \%)$ LSM menyatakan bahwa koordinasi tidak terlaksana. Pada Kabupaten Luwu Timur terdapat 16 (40\%) yang terdiri dari 4 (10\%) PIT, 6 (15\%) aparat, dan $6(15 \%)$ masyarakat menyatakan bahwa koordinasinya terlaksana, sedangkan $4(10 \%)$ yang terdiri dari 2 (5\%) masyarakat dan $2(5 \%)$ LSM menyatakan bahwa koordinasi dalam pengawasan tidak terlaksana. Dari data di atas tampak bahwa terdapat kesamaan persepsi antara responden yang ada pada Kabupaten Kutai Kartanegara dan Kabupaten Luwu Timur bahwa pelaksanaan fungsi koordinasi belum terlaksana. Dominannya jawaban responden masyarakat yang menyatakan bahwa koordinasi belum terlaksana, karena masyarakat merasakan adanya dampak negatif sebagai akibat dari belum terlaksananya koordinasi dimaksud.

Fakta ini semakin membuktikan bahwa koordinasi antar lintas sektoral memegang peranan penting serta dibutuhkan untuk terjalinnya tindakan kerja sama yang saling menunjang untuk mendapatkan keselarasan yang diharapkan akan menghasilkan kerja sama yang baik antara semua pihak sebagaimana hakikat yang sebenarnya dari tindakan koordinasi. Komunikasi atau koordinasi internal maupun eksternal yang terjalin antar lembaga merupakan proses untuk saling tukar menukar informasi dalam su- 
atu jaringan hubungan yang saling bergantung antar satu dengan yang lainnya. Kegiatan koordinasi ini sangat penting dilakukan untuk mengetahui keadaan lingkungan yang selalu berubah. ${ }^{10} \mathrm{Hal}$ ini belum tampak dalam realisasinya di lapangan baik pada Kabupaten Kutai Kartanegara mau-pun Kabupaten Luwu Timur berdasarkan jawab-an responden. Berpedoman pada UUPMB, maka koordinasi yang terpadu sudah dimulai sejak pada penetapan Wilayah Pertambangan (WP).

Pengelolaan usaha pertambangan tidak terlepas dari keterlibatan berbagai instansi sektoral, sehingga dengan demikian perlu untuk melakukan koordinasi agar pengawasan dapat terlaksana sesuai harapan. Berikut ini berbagai instansi sektoral yang terkait dengan urusan pertambangan dapat dilihat pada tabel di bawah ini.

Beragamnya peraturan perundangan yang mengatur serta lembaga yang bertanggung jawab pada bidang masing-masing mengharuskan instansi tersebut untuk melakukan koordinasi. Berdasarkan tabel tersebut, jika dikaitkan dengan pertambangan, maka keterlibatan lembaga-lembaga sebagaimana diuraikan dalam tabel diperlukan dalam hal-hal sebagai berikut.

Pertama, penilaian dokumen Amdal dan Izin Lingkungan melibatkan BLH baik pada tingkat pusat maupun di daerah; kedua, penetapan WP yang mengharuskan keterlibatan berbagai instansi sektoral secara terpadu, seperti PU, Departemen Kehutanan, BLH, BPN, Departemen ESDM, di tingkat pusat maupun Pemerintah daerah dalam menetapkan WP sebagai bagian dari tata ruang nasional untuk pertambangan; ketiga, penerbitan IUP, melibatkan Departemen ESDM jika berada pada lintas wilayah provinsi, Dinas ESDM Provinsi jika berada pada lintas kabupaten/ kota, dan Dinas ESDM jika berada pada wilayah kabupaten/ kota; keempat, urusan pemanfaatan areal pertanahan yang melibatkan Badan Pertanahan Nasional; kelima, izin pinjam pakai hutan serta alih fung-

10 Prihati, "Komunikasi Organisasi Birokrasi Pemerintahan Daerah", Jurnal Hukum Respublica, Vo.5, No.1, Tahun 2005, Hal. 123-124. si hutan dilaksanakan dengan mengharuskan keterlibatan Departemen Kehutanan baik pada tingkat pusat maupun daerah, jika areal pertambangan tersebut berada pada wilayah hutan; keenam, izin gangguan yang melibatkan Pemerintah daerah; dan ketujuh, terkait investasi, maka keharusan untuk berkoordinasi dengan instansi BKPM.

Jika dianalisis, maka koordinasi antar lintas sektoral sebagaimana dikemukakan di atas, baik dalam skala kecil maupun dalam skala besar seharusnya ada pada dinas/ instansi. Pada prinsipnya mekanisme sistem koordinasi pada lintas sektoral memiliki makna yakni di satu pihak dapat membentuk dan menuntun terwujudnya suatu kinerja lintas sektoral yang terpadu dari setiap instansi, di samping itu juga diharapkan dapat membentuk suatu sistem kerja yang lebih baik dalam suatu forum operasional koordinatif lintas sektoral yang digerakkan secara terpadu, dan lebih mudah.

Kondisi sebagaimana dimaksud dalam realisasinya belum seluruhnya terlaksana baik pada Kabupaten Kutai Kartanegara maupun pada Kabupaten Luwu Timur. Asrani Kepala Sub Bidang Pengendalian Dampak Lingkungan BLHD Kabupaten Kutai Kartanegara (wawancara tanggal 25 Oktober 2010) mengakui bahwa lemahnya koordinasi masih mewarnai pelaksanaan pengawasan dalam pengelolaan usaha pertambangan, sehingga banyak menimbulkan permasalahan saat ini. Kondisi seperti ini diperparah lagi dengan belum adanya rencana tata ruang wilayah (RTRW) yang baru setelah berlakunya otonomi (sebelumnya RTRW provinsi 1992). Demikian pula menurut Amri Kepala Sub Bidang Pengendalian dan Pemeliharaan Bapedalda Kabupaten Luwu Timur (wawancara tanggal 13 Oktober 2010) bahwa lemahnya koordinasi tampak dari sebagian pemberian izin-izin pertambangan yang tidak dilaporkan kepada pihak Bapedalda, sehingga pihak Bapedalda sendiri tidak mengetahui secara pasti keberadaan usaha pertambangan, demikian pula usaha pertambangan yang telah selesai melaksanakan usaha pertambangan tidak pernah disampaikan, sehingga pada saat Bapedalda melaksanakan pe- 
Tabel. Peraturan Perundang-Undangan Serta Lembaga Yang Bertanggung J awab

\begin{tabular}{|c|c|c|}
\hline No & Peraturan Perundang-Undangan & LembagaYang Bertanggungjawab \\
\hline 1. & $\begin{array}{l}\text { UU Nomor } 32 \text { Tahun } 2009 \text { tentang Perlindungan dan } \\
\text { Pengelolaan Lingkungan Hidup }\end{array}$ & Kementerian Lingkungan Hidup (KLH) \\
\hline 2. & $\begin{array}{l}\text { UU Nomor } 32 \text { Tahun } 2004 \text { tentang Pemerintahan } \\
\text { Daerah }\end{array}$ & Depdagri \& Pemda \\
\hline 3. & $\begin{array}{l}\text { UU Nomor } 4 \text { Tahun } 2009 \text { tentang Pertambangan } \\
\text { Mineral dan Batubara }\end{array}$ & Departemen ESDM \\
\hline 4. & UU Nomor 5 Tahun 1990 tentang Konservasi SDA & $\begin{array}{l}\text { KLH, Departemen Kehutanan, } \\
\text { Kelautan, Departemen Perikanan }\end{array}$ \\
\hline 5. & $\begin{array}{l}\text { UU Nomor } 41 \text { Tahun } 1999 \text { yang diubah dengan UU } \\
\text { Nomor } 19 \text { Tahun } 2004 \text { tentang Perubahan UU Nomor } \\
\text { 41 Tahun } 1999 \text { tentang Kehutanan }\end{array}$ & Departemen Kehutanan \\
\hline 6. & UU Nomor 26 Tahun 2007 tentang Penataan Ruang & PU \\
\hline 7. & $\begin{array}{l}\text { UU Nomor } 5 \text { Tahun } 1960 \text { tentang Ketentuan- } \\
\text { Ketentuan Pokok Agraria }\end{array}$ & Badan Pertanahan Nasional (BPN) \\
\hline 8. & $\begin{array}{l}\text { Undang-Undang Nomor } 25 \text { Tahun } 2007 \text { tentang } \\
\text { Penanaman Modal }\end{array}$ & Badan Koordinasi Penanaman Modal (BKPM). \\
\hline 9. & Hinder Ordonantie (HO) & Pemda \\
\hline
\end{tabular}

ngawasan di lapangan ternyata perusahaan tersebut sudah tutup (tidak melakukan aktivitas usaha pertambangan).

Kenyataan seperti inilah yang menjadi hambatan dalam menjadikan pengawasan sebagai instrumen penegakan hukum, oleh karena belum mencerminkan keterpaduan dan masih bersifat sektoral serta belum terjalinnya koordinasi antar instansi satu sama lain. Penjelasan yang dikemukakan oleh Asyhar Kepala Bidang Geologi Dinas Energi Sumber Daya Mineral (13 Oktober 2010) bahwa di Kabupaten Luwu Timur telah dibentuk Sistem Perizinan Satu Atap, akan tetapi terkait dengan izin pertambangan, tidak termasuk dalam sistem perizinan satu atap, sehingga tetap menjadi kewenangan Dinas Energi Sumber Daya Mineral Kabupaten Luwu Timur jika lokasi usaha pertambangan berada pada wilayah kabupaten. Pada Kabupaten Kutai Kartanegara pendelegasian sebagian kewenangan di bidang pelayanan perizinan dan non perizinan kepada Badan Pelayanan Terpadu telah diatur dalam Peraturan Bupati Kutai Kartanegara Nomor 4 Tahun 2010 yang ditetapkan pada tanggal 14 Maret 2010. Terkait dengan pertambangan, beberapa izin yang telah didelegasi dalam Badan Pelayanan Terpadu seperti, IUP Eksplorasi dan IUP Operasi produksi, Surat Keputusan Kelayakan Lingkungan (AMDAL), Surat Izin Pemantauan Lingkungan/Upaya Kelola Lingkungan
Menurut Asrani Kepala Sub Bidang Pengendalian Dampak Lingkungan BLHD Kabupaten Kutai Kartanegara (wawancara tanggal 25 Oktober 2010) bahwa fungsi Badan Pelayanan Terpadu hanyalah memfasilitasi pemberian berbagai bentuk izin. Kewenangan untuk memberikan rekomendasi tetap berada pada masingmasing instansi teknis, sehingga apabila oleh instansi teknis telah diberikan rekomendasi layak untuk memperoleh izin, maka izin akan ditetapkan. Dalam kenyataannya keberadaan badan tersebut belum berlaku secara efektif oleh karena belum lama dibentuk. Selain itu Badan Pelayanan Terpadu belum dapat menyelesaikan berbagai macam permasalahan tumpang tindih lahan di masa lampau yang hingga saat ini masih menjadi persoalan.

Gagasan pada pembentukan Sistem Perizinan Satu Atap pada Kabupaten Luwu Timur maupun Kabupaten Kutai Kartanegara menunjukkan adanya komitmen dalam melakukan penataan terhadap sistem yang ada terkait dengan perizinan dan untuk menunjukkan kepada masyarakat bahwa pemerintah telah melakukan upaya untuk melakukan pelayanan publik secara baik, walaupun dalam realisasinya belum berlaku secara efektif dan masih mengalami hambatan. Hanya saja, komitmen dalam penetapan izin secara terpadu belum ditindaklanjuti dengan pengawasan secara terpadu. Pengawasan dilaksanakan oleh instansi teknis masing-masing, sehingga belum menunjukkan adanya ke- 
terpaduan. Misalnya jadual pengawasan lapangan yang dilaksanakan sendiri-sendiri oleh instansi teknis masing-masing. Jika dianalisis, ada beberapa faktor penyebab belum terlaksananya koordinasi. Pertama, masing-masing instansi teknis memiliki program sendiri, sehingga merasa tidak perlu untuk melakukan koordinasi; kedua, munculnya egoisme sektoral oleh karena merasa lebih memiliki kewenangan untuk itu; ketiga, hambatan teknis yang menghambat pelaksanaan koordinasi, seperti, kurangnya sarana pendukung, waktu, serta biaya, sehingga koordinasi pun tidak dapat dilaksanakan.

Selain faktor-faktor yang dikemukakan di atas, kebijakan instansi pemerintah yang saling bertentangan masih dianggap sebagai faktor yang berdampak pada penegakan hukum. ${ }^{11} \mathrm{Hal}$ ini tentunya berdampak pada pengambilan keputusan serta tindakan lambatnya penyelesaian pada setiap permasalahan yang timbul. Penerapan prinsip koordinasi dalam pengawasan adalah merupakan salah satu upaya pencegahan dini dan dalam rangka untuk mengantisipasi timbulnya berbagai kemungkinan terjadinya pencemaran/perusakan lingkungan pada usaha pertambangan.

Pengawasan pada hakikatnya adalah ditujukan untuk mencegah terjadinya kekeliruan dan menunjukkan cara serta tujuan yang benar. Oleh sebab itu melalui penerapan prinsip koordinasi, maka hakikat pengawasan dapat optimal serta diharapkan dapat menjadi solusi dalam mewujudkan adanya keseimbangan, yakni pengelolaan pertambangan yang berwawasan lingkungan, sehingga dengan demikian dapat mewujudkan terselenggaranya pelaksanaan penegakan hukum pada usaha pertambangan.

Selain pengawasan sebagaimana pada uraian di atas, maka pengawasan dapat dilakukan dengan melibatkan masyarakat sebagai pengawas ekternal sebagaimana yang diatur daIam Pasal 70 UUPPLH. Pengawasan masyarakat yang dimaksud adalah pengawasan sosial yang tentunya berbeda dengan pengawasan yang dilakukan oleh pejabat yang secara langsung bertanggung jawab terhadap terselenggaranya

11 Maharani Siti Sophia, "Catatan Ketidakadilan Hukum Atas Lingkungan", Jurnal Hukum Jentera, Edisi 18, Tahun IV, 2008, hlm. 33. usaha pertambangan. Pengawasan masyarakat pada hakikatnya adalah berfungsi untuk pengendalian. Melalui pengawasan masyarakat, maka diharapkan dapat menjadi kontrol sekaligus menumbuhkan kesadaran dalam diri setiap orang tentang pentingnya perlindungan dan pengelolaan lingkungan. Oleh sebab itu, idealnya, kerja sama dalam bentuk kemitraan dengan masyarakat menjadi sangat dibutuhkan dalam melakukan pengawasan sosial terutama pada masyarakat sekitar yang memperoleh dampak langsung dari akibat usaha pertambangan.

Menurut Siti Sundari Rangkuti bahwa pengelolaan lingkungan hanya dapat berhasil menunjang pembangunan berkelanjutan apabila pemerintahan berfungsi efektif dan terpadu. ${ }^{12}$ Relevan dengan pendapat yang dikemukakan Siti Sundari Rangkuti maka, perlunya kebijakan, serta standar yang sama dalam pengawasan, sehingga dapat membuktikan bahwa secara internal prinsip koordinasi telah diterapkan meIalui kebijakan menetapkan sistem perizinan terpadu. Secara eksternal, peran masyarakat sebagaimana dimaksudkan dalam Pasal 70 UUPLH diperlukan dalam menunjang sistem yang terpadu. Hal ini dengan disertai harapan dapat mendukung optimalnya prinsip tujuan pelaksanaan pengawasan yakni, sebagai upaya preventif dalam mewujudkan penegakan hukum. ${ }^{13}$ Menurut Nabiel Makarim bahwa penegakan hukum lingkungan meliputi, pengembangan sistem satu atap. ${ }^{14}$ Model seperti ini dapat diterapkan di Indonesia, untuk meminimalkan terjadinya pencemaran/ kerusakan lingkungan.

Berdasarkan uraian di atas, maka untuk optimalnya tugas pengawasan dan sebagai alternatif solusi untuk mengantisipasi terjadinya pencemaran/kerusakan lingkungan pada usaha pertambangan, maka diperlukan berbagai upaya. Melalui upaya tersebut, maka diharapkan dapat mewujudkan praktik pertambangan yang

12 Siti Sundari Rangkuti, 2006, Hukum Lingkungan dan Kebijakan Lingkungan Nasional, Edisi Ketiga, Surabaya: Airlangga University Press, h. 126.

13 Fenty Puluhulawa, "Kewenangan Perizinan Dalam Pengelolaan Lingkungan Pada Usaha Pertambangan Mineral dan Batubara", Jurnal Hukum Legalitas, Vol 3, Nomor 2, 2 Agustus 2010, hlm. 7.

14 Absori, "Penegakan Hukum Lingkungan Pada Era Reformasi", Jurnal Ilmu Hukum, No. 2, Vol 8, Universitas Muhammadiyah Surakarta, 2005, hlm. 221. 
baik (good mining practice). Ada dua upaya yang perlu dilakukan. Pertama, perlunya pembentukan sistem perizinan lingkungan yang terpadu seperti halnya di Belanda untuk memudahkan pelaksanaan koordinasi, serta optimalnya pengawasan, sehingga dengan demikian tindakan kerja sama saling menunjang untuk mendapatkan keselarasan pada akhirnya akan menghasilkan kerja sama yang baik antara semua pihak, sebagaimana prinsip koordinasi. Sistem perizinan lingkungan yang terpadu diharapkan akan meningkatkan efisiensi dari segi waktu dan biaya; dan kedua, perlunya keterlibatan masyarakat, terutama di sekitar tambang yang memperoleh dampak langsung dari usaha pertambangan ataupun melalui LSM relevan, untuk menjalin kemitraan berperan dalam melakukan pengawasan sosial, yang berupa pemberian saran, usul serta kepedulian terhadap lingkungan sebagaimana harapan Pasal 70 UUPLH untuk mendukung optimalnya pelaksanaan pengawasan.

\section{Penutup \\ Simpulan}

Berdasarkan uraian pada pembahasan di atas, maka disimpulkan bahwa baik dilihat dari segi perencanaan, maupun koordinasi intensitas pelaksaaan pengawasan belum dilaksanakan secara optimal, sehingga belum mendukung terwujudnya pertambangan berkelanjutan dan berwawasan lingkungan melalui upaya penegakan hukum. Fakta ini dapat ditemui pada strategi perencanaan terkait dengan pengawasan pengelolaan lingkungan yang telah dilakukan, walaupun dalam kenyataannya belum dilaksanakan secara terpadu dan terkoordinasi. Mekanisme koordinasi antar lintas sektoral yang lemah, sehingga berdampak pada belum optimalnya pengawasan. Oleh sebab itu dibutuhkan kelembagaan melalui sistem perizinan lingkungan yang terpadu. Pembentukan sisitem perizinan yang terpadu diharapkan akan memudahkan dalam pelaksanaan perencanaan sehingga dapat melaksanakan koordinasi yang efektif dan efisien, sehingga dengan demikian mendukung pelaksanaan penegakan hukum melalui upaya yang sifatnya preventif melalui pengawasan.

\section{Daftar Pustaka}

Absori. "Penegakan Hukum Lingkungan Pada Era Reformasi". Jurnal IImu Hukum, No. 2, Vol 8 2005;

Gunawan. "Hak Atas Lingkungan dan Tanggung J awab Lingkungan Korporasi". J urnal Hukum J entera, Nomor 18, Tahun IV, 2008;

Hamidi, Jazim dan Mustafa Lutfi. "Eksistensi Komisi Ombudsman Nasional dalam Mewujudkan Good Governance". Majalah Hukum Varia Peradilan, Edisi April 2009;

Hasibuan, Puspa Melati. “Dampak Penambangan Bahan Galian Golongan C Terhadap Lingkungan Sekitarnya Di Kabupaten Deli Serdang". J urnal Equality, Vol. 11, No. 1, Februari 2006;

Prihati. "Komunikasi Organisasi Birokrasi Pemerintahan Daerah". Jurnal Hukum Respublica, Vo.5, No. 1, Tahun 2005;

Puluhulawa, Fenty. "Kewenangan Perizinan dalam Pengelolaan Lingkungan Pada Usaha Pertambangan Mineral dan Batubara". J urnal Hukum Legalitas, Vol 3, Nomor 2, 2 Agustus 2010;

-.-.-.-. "Substansi Hukum Tentang Pengawasan Izin Pada Usaha Pertambangan". J urnal Pelangi IImu, Vol 3 Nomor 4, 4 September 2010;

Rangkuti, Siti Sundari. 2006. Hukum Lingkungan dan Kebijakan Lingkungan Nasional. Edisi Ketiga. Surabaya: Airlangga University Press;

Ridwan. 2006. Hukum Administrasi di Daerah, Bandung: PT Raja Grafindo Persada;

Sophia, Maharani Siti. "Catatan Ketidakadilan Hukum Atas Lingkungan". J urnal Hukum J entera, Edisi 18, Tahun IV, 2008;

Suhala, Supriatna. 2009. Penyelesaian Konflik Pertambangan Butuh Lembaga Khusus". Tersedia di website www.majalahtambang.com, diakses tanggal 2 April 2009;

Wignyosoebroto, Soetandyo. "Sedikit Penjelasan Tentang Kajian-Kajian Hukum Dari Perspektif IImu Sosial". J urnal Warta Hukum dan Masyarakat, No 1 Tahun ke 1 November 1995;

Yetti, Yusni. "Analisis Kebijakan AMDAL Dalam Mencegah Kerusakan". Lembaran Publikasi Lemigas, Vol. 41, No. 3, Desember 2007. 
316 J urnal Dinamika Hukum Vol. 11 No. 2 Mei 2011 